\title{
Natural events and unnatural disasters
}

\author{
Fire has always been one of the more dramatic routes by which humanity and the plant kingdom \\ interact. Forest management practices, urban planning and global warming are conspiring to make the \\ relationship ever more destructive.
}

In the past month, wildfires around the globe have filled news feeds with devastating pictures and reports. In Italy, hundreds of people evacuated by boat from Sicily; in the United States, thousands forced from their homes in California, Oregon and Colorado; and in Canada, over 200 separate fires raging through British Columbia, generating the area with enough smoke to be seen from space. Areas in Australia, Portugal, Scotland and South Africa are still recovering from wildfires earlier in the year, with some of those areas seeing their worst fire danger ever, and rightful fears that already historic fire dangers will only worsen in years to come.

In this issue of Nature Plants, Patrick Roberts and colleagues discuss prehistoric influences of humanity on tropical forests, including the deliberate setting of blazes by indigenous peoples (article no. 17093). In his 2011 book 1493, Charles Mann discussed research showing that forests and grasslands in the eastern United States were so intensively managed through fire that when the indigenous tribes were wiped out after colonization, the rise in undergrowth sucked in so much carbon it caused the Little Ice Age. However, development in many societies has led to forest management that is more about timber production than about the sustainable use of forest ecosystems, let alone understanding the natural processes that govern them.

Over the most recent century, wildfire suppression has been the norm; the US Forest Service used to have a ' 10 a.m. rule' encapsulating the goal of putting every forest fire out by that time the next day. As a consequence, many forests and grasslands across the world have lost out on the services that fire provides for plant and animal species alike, such as opening seeds and regenerating the soil for new growth. This has also led to a vast increase in flammable material, risking ever larger fires, such as that in Yellowstone National Park in 1988 when nearly $45 \%$ of the park (some 400,000 hectares) burned for months (Christensen, N. L. et al., Bioscience 39, 678-685; 1989).

While fires have been part and parcel of life in almost every ecosystem, human activity is exacerbating the impacts on our world. Any mention of climate change impacts will invariably refer to wildfires, as recent evidence suggests that in the western United States alone, fires are happening four times more often and burning six times more land area than just a few decades ago. As Gary Ferguson details in his new book Land on Fire: The New Reality of Wildfire in the West, wildfires in North America account for 3\% of all fires but over $90 \%$ of all land area burned, and the 'fire season' in the American West is approximately 10 weeks longer than it was in 1982. The superintendent of a team of hotshots (experienced firefighters who hike into a wildfire to try to contain it) is quoted in the book as saying that the years surrounding the Yellowstone fire of 1988 "seemed like such exceptional years. And now they're pretty much routine".

Each year brings reports of ever hotter temperatures and thus ever larger bushfires in Australia, and in many parts of the world, fire season has become both more regular and more intense in line with climate change projections due to changes in temperature and precipitation. Even the fires themselves fuel faster climate change. Carbon stored for decades or even centuries in temperate forests is released into the atmosphere and the remaining forests have reduced capacity for absorbing emissions, generating yet further feedback loops to somehow incorporate into our models for future global warming.

Beyond the larger ecological changes, wildfires affect human health in profound ways. Indonesia's uncontrolled fires in 2015 (set by farmers and plantation owners wanting to clear land for more agriculture) generated so much air pollution that the resulting haze may be responsible for nearly 100,000 premature deaths in Southeast Asia since then. Fires cause smaller and finer particulate matter that can spread more widely than many people think, affecting populations far from the source of a fire even if the smoke cannot be seen directly. For example, in 2002 in Baltimore, Maryland, particulate matter levels jumped 30 -fold due to a fire over a thousand miles away in Canada (Sapkota, A. et al., Environ. Sci. Technol. 39, 24-32; 2005).

Then there are the monetary costs of fires. Ferguson states that while the federal government in the United States was spending $\$ 600$ million annually on fighting fires in 1995, in recent years that bill has exceeded $\$ 3$ billion. More often than not, the US Forest Service has to ask Congress for more funds in the middle of the fire season whilst fighting multiple fires, as individual American states do not have the budget capacity to absorb the escalating costs. That present reality for an economic superpower may well become an insurmountable future reality for many developing countries. The Indonesian government estimates that their conflagration cost the country at least $\$ 50$ billion in damages and lost value and productivity, let alone the human costs of the 100,000 premature deaths mentioned above.

At the same time that fires are getting larger and lasting longer, they are also coming into contact with more and more people. Cities and towns worldwide have been largely unable, or unwilling, to contain their sprawl and thus encroach onto wilderness lands that had served as a buffer zone of sorts. Wealthy individuals go further, building homes in the middle of those lands, homes that are then at risk of going up in flames (and risking the lives of firefighters as a consequence). There is increasing focus on this urban-wilderness interface from scholars who highlight the incongruity of labelling destructive wildfires as 'natural disasters' when people willingly put themselves in the line of fire. Mike Davis even titled the chapter on California wildfires in his 1998 book Ecology of Fear "The Case for Letting Malibu Burn", a jeremiad against taxpayers repeatedly having to pay to protect and then rebuild mansions (through emergency services and fire insurance) in one of the most wildfire-prone areas of the planet.

While fire is one of the oldest and most powerful forces of nature on Earth, the problems that societies around the world face in regard to these fires are in many cases problems of their own making. The billions of dollars spent every year in fighting fires are already proving to be too much for governments, yet billions more will be necessary to prevent ever larger catastrophes. Changes in urban growth patterns and more accommodating management practices will be needed to maintain a mutually beneficial truce between humanity and the plant kingdom in places where fire is a natural and necessary part of life. 